\title{
Analysis of the Santa Isabel de las Lajas Municipality in the Cienfuegos Province of the Republic of Cuba, for a local development proposal based on tourism
}

\section{Análisis del Municipio Santa Isabel de las Lajas en la Provincia de Cienfuegos de la República de Cuba, para una propuesta de desarrollo local a partir del turismo}

\author{
RODRÍGUEZ-ALVAREZ, Nely† \& CAMELO-AVEDOY, José Octavio* \\ Universidad Autónoma de Nayarit, MCDST. Mexico. \\ ID $1^{\text {st }}$ Author: Nely, Rodríguez-Alvarez / CVU CONACYT ID: 972018 \\ ID $1^{\text {st }}$ Co-author: José Octavio, Camelo-Avedoy / ORC ID: 0000-0002-5722-3032, CVU CONACYT ID: 99469
}

\begin{abstract}
In the present investigation a socioeconomic analysis and regional study was carried out in the Santa Isabel de las Lajas municipality of the Republic of Cuba, with the purpose of observing the economic relevance of the tourist connection of this town with the city of Cienfuegos, cataloged the latter, Cultural heritage of humanity in 2005. The theoretical framework used is that of Regional Development, from the perspective of the school of Enrique Gallicchio Pagani and the research approach used is that of Participatory Action Research. For which we worked with the model proposed by Martí Olivé in his book "Research - participatory action. Structure and phases". The analyzed data were obtained through surveys of the local population and interviews with local actors and the municipal government. Finally, the findings of the research and the conclusions of the work are presented.
\end{abstract}

Regional development, Tourism, Socioeconomic conditions

\begin{abstract}
Resumen
En la presente investigación se realizó un análisis socioeconómico y estudio regional en el municipio Santa Isabel de las Lajas de la República de Cuba, con el propósito de observar la pertinencia económica de vinculación turística de esta localidad con la ciudad de Cienfuegos, catalogada, esta última, patrimonio cultural de la humanidad en el año 2005. El marco teórico utilizado es el de Desarrollo Regional, desde la óptica de la escuela de Enrique Gallicchio Pagani y el enfoque de investigación utilizado es el de Investigación-acción participativa. Para lo cual se trabajó con el modelo propuesto por Martí Olivé en su libro "La investigación acción participativa. Estructura y fases". Los datos analizados se obtuvieron mediante encuestas realizadas a la población local y entrevistas a actores locales y del gobierno municipal. Finalmente se exponen los hallazgos que arrojó la investigación y las conclusiones del trabajo.
\end{abstract}

Desarrollo regional, turismo, condiciones socioeconómicas

Citation: RODRÍGUEZ-ALVAREZ, Nely \& CAMELO-AVEDOY, José Octavio. Analysis of the Santa Isabel de las Lajas Municipality in the Cienfuegos Province of the Republic of Cuba, for a local development proposal based on tourism. Journal Economic Development. 2021. 8-26:1-11.

\footnotetext{
* Correspondence to Author: (E-mail: ocameloa@uan.edu.mx).

$\dagger$ Researcher contributed as first author.
} 


\section{Introduction}

Many expectations are placed around territorial heritage (natural, cultural or landscape) when it comes to boosting or diversifying tourism, both in low-income countries and in developed countries. However, it is not always realized, on the one hand, that not all heritage has a tourist dimension and, on the other, that the economic dynamization based on tourism and cultural facilities or infrastructures has important limitations. In current Human Geography, even though research into tourism is fairly recent, the limits of structural analyses of tourism are becoming evident, as well as the need to reinforce critical approaches, the convenience, from a social approach, of investigating the socio-spatial practices of tourists, questioning the fact that tourism is understood essentially as an economic activity. (Troitiño M. and Troitiño L., 2016).

The origin of local economic development initiatives in Latin America does not respond to a single cause. Many of these initiatives have arisen as a reaction to situations of local economic crisis and the lack of appropriate policies from the central level of the state to address these situations (Leite, 2000). The case of Cuba is also an example of this.

The 1990s in Cuba marked the life of the country: the economic crisis or the so-called special period that arose with the fall of the socialist camp of the USSR and the intensification of the US blockade of Cuba, provoked the loss of fundamental export markets and $80 \%$ of imports. The economy was paralysed, production levels fell, basic services deteriorated, etc. From balanced, centrally planned development, with guaranteed inputs as well as technologies, there was a transition to survival and uncertainty in a scenario of social re-stratification and expansion of inequalities in the most diverse areas (Espina, 2010, as cited in Matín, Olite \& Robaina, 2012, p. 2). This gave rise to the need to seek development alternatives at the regional level that were capable of guaranteeing food self-sufficiency and the extension of the agricultural sector. However, according to data presented in the magazine Desarrollo Local Sostenible and corroborated with the Municipal Delegation of Agriculture of Santa Isabel de las Lajas, the levels of agricultural yields achieved so far have been low, due to insufficient use of all productive soils and their increasing degradation.
In some areas of the territory the soils are not very productive and sandy, there is little strengthening of productive forms, in terms of animal traction and lack of irrigation systems. There is also insufficient community participation in the management of local development, as well as a high migratory flow from rural to urban areas and from urban areas to other cities.

For these reasons it has been necessary to look for other forms of production. Starting from the following questions: What would allow us to convert the territorial heritage resource of the municipality of Santa Isabel de las Lajas into a tourist product that contributes socio-economic values? How can economic development be achieved through heritage tourism in the municipality of Santa Isabel de las Lajas, with a sustainable approach? How could a tourist link be established between the city of Cienfuegos and the municipality of Santa Isabel de las Lajas? A diagnosis was carried out to show the socio-economic reality of the region, the real possibilities of establishing tourism, with knowledge of the resources to be used and, above all, the willingness of local society to implement this type of activity in the municipality.

The theoretical framework used was that of Local-Regional Development, with a focus on the school of Enrique Gallicchio Pagani. The research model used is that of Participatory Action Research, which allows the process of searching for information to be directly involved with reality, involving the actors who can benefit from the results obtained in the research process. This also offers the possibility of joint reflection and of finding relevant aspects that might be overlooked in traditional social science research (Martí Olivé, 2016).

The paper is divided into the following sections: Chapter I: methodology, Chapter II: theoretical framework, Chapter III: characterisation of the population, Chapter IV: findings and discussion, and finally the conclusions are set out. 


\section{Methodology}

The first stage of the research, following the aforementioned model, was the pre-research stage, where the research problem and the proposed objectives were analysed and determined. In the first fieldwork, a diagnosis was carried out that led to a contextual knowledge of the territory and an approach to the proposed problem, for which the latest economic reports of the Municipal Government Office were reviewed, as well as socio-economic data collected in the National Statistics Office of the municipality. The collection and analysis of information on heritage, cultural and natural tourism in general was carried out, and then all the relevant information on the locality in relation to the subject of tourism and local development. We also read and systematised all available information on: previous planning, studies on culture and heritage, academic work (studies, books, theses, etc.), visited sites that are national monuments or heritage sites, compiling information and photographic images to make an inventory of tourism resources, and reviewed projects that had already been carried out, for possible linkage with the study.

On the other hand, the identification of relevant actors and possible points of support in the state, the municipality, public institutions, cultural and heritage organisations, and the community in general was carried out. Their interests, commitments and available resources were detected, for which in-depth interviews were conducted with government representatives, directors of state-owned companies and social actors with leadership within the municipality. Surveys were also carried out among the general population. In order to carry out the study, only the population of the municipal capital and some nearby areas were taken into account, which is where the largest number of people in the municipality are concentrated; from this segment, further discrimination was carried out. In order to determine the size of the sample, Simple Random Sampling without replacement was used. Thus, out of a total population of 14284 inhabitants, a sample of 375 persons was taken and so far 210 surveys have been carried out for $56 \%$. The formula used to calculate the size was:

Sample size $=$

$$
\frac{\frac{z^{2} \times p(1-p)}{e^{2}}}{1+\left(\frac{z^{2} \times p(1-p)}{e^{2} N}\right)}
$$

Where:

$\mathrm{N}$ : population size, with decimals),

e: margin of error (percentage expressed

\section{z: Z-score}

\section{Theoretical framework}

Local development is a concept that has been proposed with the aim of reactivating the social and economic dynamics in a local dimension "Local development refers to processes of capital accumulation in cities, counties and specific regions. The availability of a supply of labour, sufficiently qualified for the tasks it performs, and with little conflict, together with a business and organisational capacity, strongly linked to the local productive tradition and a culture attentive to innovation and change, favours the accumulation of capital in local productive systems. These processes of economic development are characterised by the systemic organisation of production units, which favours the competitiveness of local companies in national and international markets. The organisation of the local productive system into networks of companies favours the generation of economies of scale and the reduction of transaction costs and, therefore, increasing returns and economic growth". (Vázquez, 2000, p.5).

From this perspective, the concreteness of local development does not occur in itself, that is, it is not at the abstract level, its representation in the concrete requires the linking of local agents that generate influence to achieve it "Local development implies the concertation between the agents - sectors and forces - that interact in a given territory and the permanent, creative and responsible participation of citizens in a common project of diverse dimensions. These include the generation of economic growth, equity, social and cultural change, ecological sustainability, gender focus, quality and spatial and territorial balance. 
The aim of local development is to raise the quality of life of each citizen living in that territory, contribute to the country's development and adequately face the challenges of globalisation and the transformations of the international economy". (Enriquez, 1997, as cited in Gallicchio, Camejo, Marchesi and Daguerre 2005, p.40).

It is worth noting that local development, despite its concrete dimension of a population space, is undeniably related to the regional and even global context, both in terms of factor income and its link to the goods generated outside, it is therefore not something that can be circumscribed entirely to the local, but the local is based on the organisation of the factors of production and the organisation of local actors "Local development must consider and be considered in relation to the contexts in which it operates, mainly the regional and national levels, but above all globalisation. (...) Local development appears as a new way of looking at and acting from the local level in this new context of globalisation. The challenge for local societies is posed in terms of inserting themselves into the global arena in a competitive manner, capitalising as much as possible on their capacities through the strategies of the different actors involved". (Gallicchio, 2003, p. 1, 2).

It is, local production, as well as the role of the productive agents, in their organisational capacity, even with their exogenous relationship with regard to the input/output of the productive requirements "Local development consists of growing from an endogenous point of view, and also obtaining external, exogenous resources (investments, human resources, economic resources), as well as improving the capacity to control the surplus that is generated at the local level. The challenge is then how much the actors are capable of using the resources that pass through, and remain, in their territorial sphere, to improve the living conditions of the inhabitants". (Gallicchio, 2003, p.5). Thus, the approach takes on nuances that allow us to moderate the radicalism, misunderstood in many cases, of the local level.
Local economic development can be expressed in two senses, through the empowerment of the economic activities already carried out, in their insertion into a process, if it is allowed, democratisation of the benefit of the production that is carried out; in another sense, it can be carried through a change of the economic structure, not necessarily radical, but which is established through the change of production and its conglomerate re-organisation of the factors of production and the organisation of the same. The above stated, for the local level, as an object of change, "can be defined as a process of growth and structural change that by utilising the existing development potential of the territory leads to the improvement of the well-being of the population of a locality or a region. When the local community is able to lead the process of structural change, the form of development can be agreed upon as endogenous local development". (Vázquez B., 1988, as cited in Vázquez B., 2000, p.5).

In order to achieve production and income distribution in a homogeneous way among its inhabitants, where integration is through participation in the process of reasonable use of resources "Local economic development can be defined as a participatory development process that promotes collaborative agreements between the main public and private actors of a territory, enabling the design and implementation of a common development strategy based on the use of resources and local competitive advantages in the global context, with the ultimate goal of creating decent employment and stimulating economic activity" (Rodriguez-Pose, 2002, as Rodriguez-Pose, 2002, as Rodriguez-Pose, 2000, p.5). (Rodríguez-Pose, 2002, as cited in Alburquerque, 2004, p. 19).

The local economic development approach is the theoretical and practical means to achieve an increase in the levels of social welfare, not the generation of wealth and its accumulation in a small number of the local population; Given the characteristics and the economic context of Latin American countries, the processes of local development are mainly focused on micro and small enterprises, productive sectors displaced from the market and human groups with serious difficulties of accessibility or stability in the employment market. 
For this reason, local economic development initiatives need to include components with an impact on reducing urban and rural poverty and improving employment opportunities at the local level, such as: labour intermediation and guidance, microcredit, specific training, technical support for productive projects that enable diversification and entry into value-added markets (fair trade, organic production), among others. A central point is how to articulate local economic development initiatives not only with national economic policies but also with social policies". (Gallicchio, Camejo, Marchesi and Daguerre 2005, p. 53).

State-local development link In praxis, it is established as a relationship that makes it possible to manage potentialities in order to achieve development. In this respect, there may be various ways of implementing this link; some may be in the form of a vertical plan, but experience indicates that work must start at the grassroots and work upwards, where there is space to develop potentialities; However, it must be made explicit that in the end it is the circumstances of the historical moment that determine what is appropriate "The form of organisation of the state (federal, regional or centralised) and, above all, the effectiveness of the processes of administrative and political decentralisation, contribute significantly to the emergence and expansion of local initiatives. When the state is configured as federal or regional, the design and implementation of economic development strategies are strongly affected, mainly due to changes in the mechanisms of state functioning and power relations. In federal and regional states, the institutional reality reinforces the potential for diffuse development existing in the territory. When the Constitution recognises and strengthens the objectives of the municipalities and regions (federal states), economic development does not necessarily have to be seen in terms of the general interests of the State, but on the contrary, endogenous local development appears at least as a possible strategy". (Vázquez B., 2000, p. 22).
The participation of the State in the processes of promotion and local economic development policies allows for a process of regional or local governance, depending on the dimension of the work, to be more consolidated, since the relationship in this process includes the support and intervention of the State, that is, to place power within the reach of the population and its processes and interests of economic development "Local development improves governance at all levels, basically because it places the government and power within the reach of the people. A first challenge is to recover the government-citizen link, a key element for the legitimacy of the forms of government that we have given ourselves (...) one of the attributes of local development is that it brings power closer to the citizens. Closeness to the problems and to the decision-makers can allow for democratic improvement. The pressure of globalisation is forcing local authorities to reconstruct the relationship between the public and private sectors at the local level, as well as to rethink the most basic aspects of their capacity to govern. Articulating this network is not easy, it implies political will and also new capacities". (Gallicio, 2013, p. 16, 17).

\section{Characterisation of the population.}

The data reflected in this section are taken from the report of the Municipal Delegation of Agriculture of the municipality of Santa Isabel de las Lajas and the Municipal Government Report on the population outlook, both documents from 2018.

Location The municipality of Santa Isabel de las Lajas was founded on the 29th of April 1860, belonging at that time to the then province of Las Villas until 1976, when it became part of the province of Cienfuegos, also created on that date. It is located in its northern and eastern portions at 220 27'latitude north and 80018 'longitude west, its limits are: to the north with the municipality of Santo Domingo in the province of Villa Clara, to the east with the municipality of Ranchuelo in the province of Villa Clara, to the south with the municipalities of Cruces and Palmira and to the west with the municipality of Rodas in the province of Cienfuegos (figure 1). 


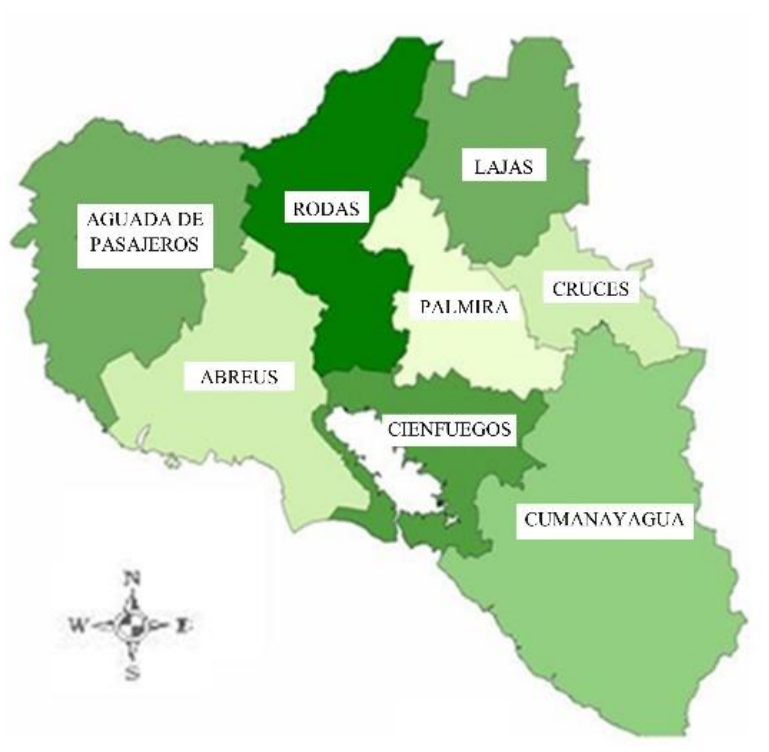

Figure 1 Location of the municipality of Santa Isabel de las Lajas

Source: Provincial Directorate of Physical Planning, Cienfuegos 2011

It has a geographical area of $432.65 \mathrm{Km} 2$ $(43150.0 \mathrm{Ha})$ which represents $10.3 \%$ of the province's territory, with $94 \%$ of the area belonging to the state sector and its fundamental economic base is agriculture.

\section{Communication}

The interaction of Lajas with the province is guaranteed by the Cruces Lajas Santo Domingo road, which intersects with the National Highway that is $4 \mathrm{~km}$ from the settlement of the capital. The municipality has a population of 21826 inhabitants, 11295 males and 10531 females, $69.6 \%$ of the population (15180) is urban and 30.4\% (6 646) is rural, it has 5 urban and 23 rural settlements, with an urbanisation index of $67 \%$. In addition, it has a population density of 50.9 inhab/Km2 and has a housing stock of 8766 dwellings. The main communication routes are the National Highway that crosses it from west to east, a railway that crosses the municipality from south to north and connects it with the territories of Cruces and Santo Domingo, as well as a road that connects the municipal capital with the road from Cruces to Ranchuelo.

\section{Key economic sectors}

The main economic sectors of the municipality are agriculture, industry and services. In the agricultural sector, the main products are: sugar cane, various crops, fruit trees, cattle and small livestock.
In the industrial sector, there is the sugar industry, made up of the Central Ciudad Caracas and the food industry represented by bakeries, a sweet shop and a fruit and vegetable canning factory, as well as state and private construction material production centres that contribute to the local construction materials programme.

\section{Education}

The municipality has 2 children's circles, 30 primary schools, a basic secondary school, a polytechnic institute, 2 special education schools, a trade school and an adult education school. Primary education has 148 teachers and an enrolment at the beginning of the school year of 1773 pupils, secondary education has 94 teachers and 1200 pupils and technological education has 79 teachers and 545 pupils.

\section{Health}

The municipality has one public polyclinic and 29 family doctor's surgeries $(100 \%$ of the population is covered by the free medical service). There are 69 doctors, with a ratio of 342.6 inhabitants/doctor and 1688.5 inhabitants/stomatologist.

\section{Relief}

The territory covers three relief units: the northern portion and part of the centre belongs to the Manacas plain, from the centre to the south mostly to the Cienfuegos plain and to the southeast to the heights of Santa Clara. The relief is varied in correspondence to the particular morphological and structural characteristics of the territory, it is flat and slightly undulating, moderately dissected, with a well-defined and developed fluvial network, an area of great agricultural value for the development of crops, according to the altitude it is distinguished within the Great Plains level and within these the following types are distinguished:

Flat plains: this type of relief is characterised by being very flat areas lacking significant micro-reliefs coinciding in alluvial planes, depressive zones, marshy and pre-marshy areas, the accumulative processes are more intense than the erosive ones and a vertical dissection index of less than 2 m.km-2. 
Undulating plains: these are flat surfaces with certain irregularities in their micro relief, well drained soils, with alternating cumulative, erosive and denudation processes.

Pre-mountainous - hilly zone level (60 to $80 \mathrm{~m}$ ), the value of vertical dissection ranges between $2 \mathrm{~m} \cdot \mathrm{km}^{-2}$.

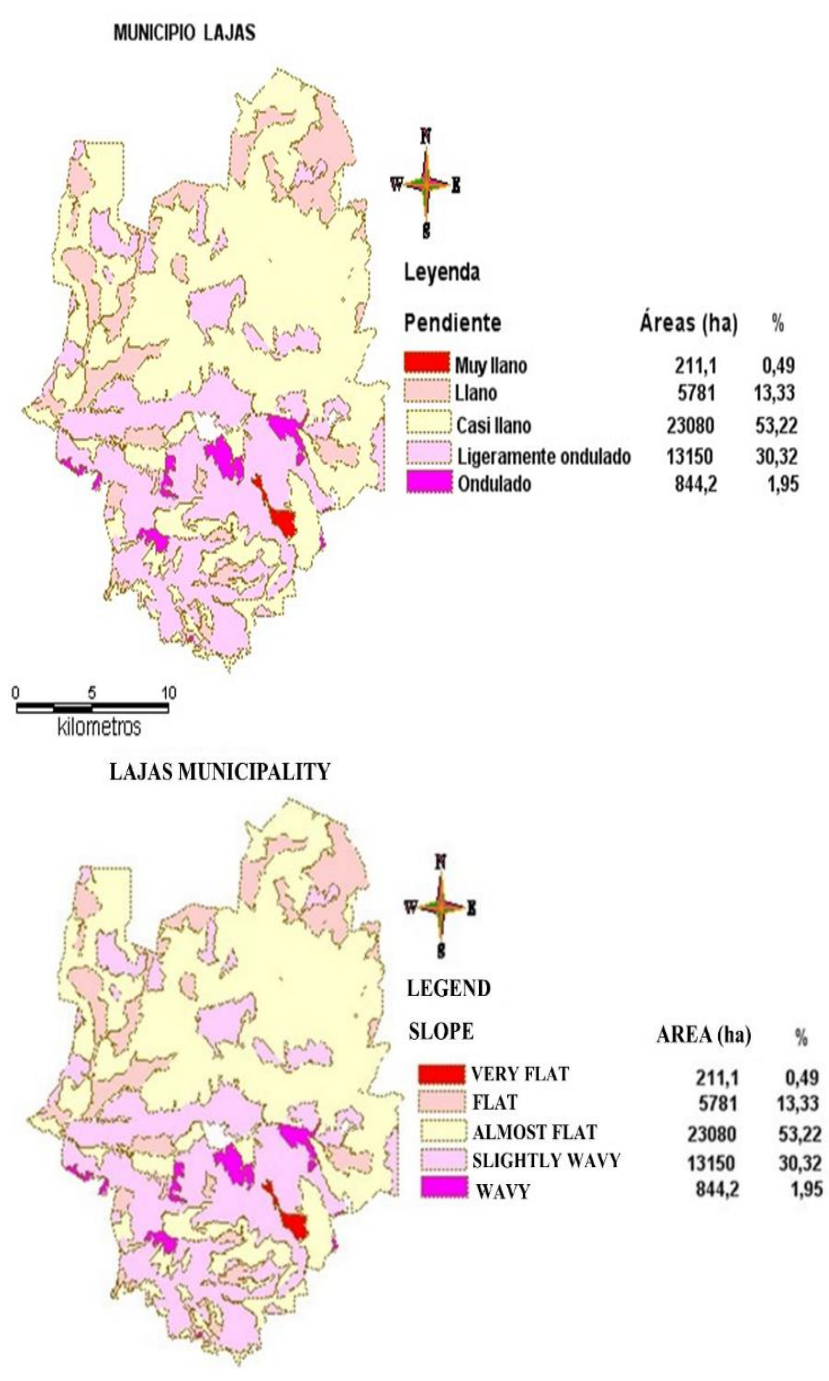

Figure 2 Map of soil slopes in the municipality of Santa Isabel de las Lajas

Source: Unidad Científico-Tecnológica de Base Suelo Cienfuegos, 2013

\section{Hydrography}

The municipality of Santa Isabel de las Lajas is located within the Damují surface hydrographic basin and the Anaya surface hydrographic subbasin.
The hydrographic basin of the Damují river has a regulation in the Lajas river, known by the El Salto reservoir, which has an area of $65.9 \mathrm{~km}$, its tributaries have a length of 180.0 $\mathrm{km}$, its fluvial density is 2,327 with an average height of $86.1 \mathrm{~m} . \mathrm{nm}^{-1}$, the slope is $19.77 \mathrm{0} / 00$, it has a runoff lamina of $338.0 \mathrm{~mm}$, with an average flow of $0.852 \mathrm{~m} 3 . \mathrm{s}-1$ and has a runoff modulus of 10.718 L.s-1.km-2. Its water is used for irrigation and its users are downstream.

\section{Surface and groundwater}

The municipality of Santa Isabel de las Lajas has a reservoir, El Salto, with a capacity of $9.5 \mathrm{Hm} 3$, which is used for crop irrigation as well as micro reservoirs, which are also used by farmers for livestock. Groundwater is also used for these purposes.

Portable and semi-stationary sprinkler irrigation techniques are used in the case of fruit trees and livestock; this technique is also being incorporated in various crops. There is no tradition of sprinkler irrigation with central pivot machines or reels, and only the technique of gravity irrigation is used in cultivation areas of farmers near the reservoirs and micro-reservoirs.

\section{Climate}

The climate of the municipality of Santa Isabel de las Lajas is tropical semi-humid with hot and rainy plains, favourable for agricultural and sugar cane development. The average rainfall intensity varies between 18 and $25 \mathrm{~mm}$.day-1, the frequency of rainy days per year is $70 \mathrm{~mm}$. The average annual relative humidity is $80.7 \%$, which is high from June to January (81 to $86 \%$ ) and low from February to May (73 to $79 \%$ ), as is the temperature. The temperature is $6.70 \mathrm{C}$ with an annual average of $23.70 \mathrm{C}$, the annual average maximum is $29.50 \mathrm{C}$, with a maximum in July. The average annual minimum is 18.70 $\mathrm{C}$, with a minimum in February. The municipality receives the greatest influence in the province from the trade winds of $60.7 \%$.

\section{Culture}

The municipality is characterised by a rich traditional popular culture, among which are the "guateques", the "parrandas campesinas", the festivities of the day of the "lajero" which are celebrated in June of each year as a revival of tradition. 
There is a deep-rooted popular tradition that is evident in the religious festivities such as the wakes for saints, the "toques de bembé" and the feast of San Antonio which is celebrated every 13 June in the Casino de los Congos (a place of worship and Afro-Cuban traditions). The cultural institutions maintain stability in their services, among which are: the bookshop, the cinema, the museum, the library, the house of culture, the Benny Moré square and the municipal concert band. There are two nationally recognised amateur groups in the municipality, Lira Tropical of the peasant genre and the Grupo Folklorico Makuta, of the AfroCuban genre. Because of the cultural transcendence of Benny Moré, son of this town, the sites linked to the life and work of this brilliant artist are marked. The existence of a coat of arms and the anthem of Lajas are part of our local identity.

\section{Findings and discussion.}

\subsection{Socio-economic aspects of the population of Santa Isabel de las Lajas.}

From the surveys carried out among the local population, the results obtained are reflected in the following graphs. Firstly, the level of schooling of the population surveyed so far is shown. Out of a total of $210,45 \%$ of the population has a university degree, $38 \%$ has a bachelor's degree, $13 \%$ has a high school degree and $4 \%$ of the population has an intermediate technical degree.

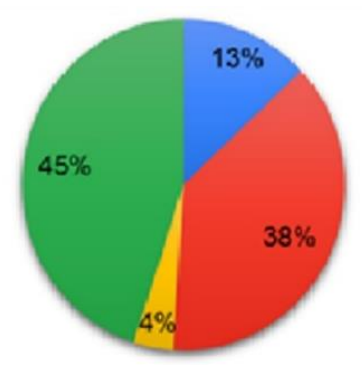

= SECONDARY

$=$ HIGH SCHOOL $=$ TECHNICAL

= UNIVERSITY

Graphic 1 Level of schooling of the population of Santa Isabel de las Lajas, Cienfuegos; Cuba

Source: Own elaboration
As can be seen in the previous graph, the level of schooling of the population of Santa Isabel de las Lajas is quite acceptable, given that none of those surveyed have less than a high school diploma; this allows us to assume that this level of schooling offers strengths for the population to be integrated into the discussion, analysis and construction of the economic linkage proposal, with an emphasis on tourism, with the city of Cienfuegos.

But having a population with such characteristics in terms of schooling has another advantage for the present research: having a higher level of schooling will allow the population to have a better interaction with the eventual tourist who arrives in the locality, especially when remembering that the tourist potential of the population of Santa Isabel de las Lajas is based on cultural and historical tourism.

The second graph shows the degree of occupation in the municipality of Santa Isabel de las Lajas, of the total number of people surveyed (210), $73.4 \%$ work, $7.9 \%$ study, $7.4 \%$ are housewives, another $7.4 \%$ are retired and only $4.43 \%$ are unemployed.

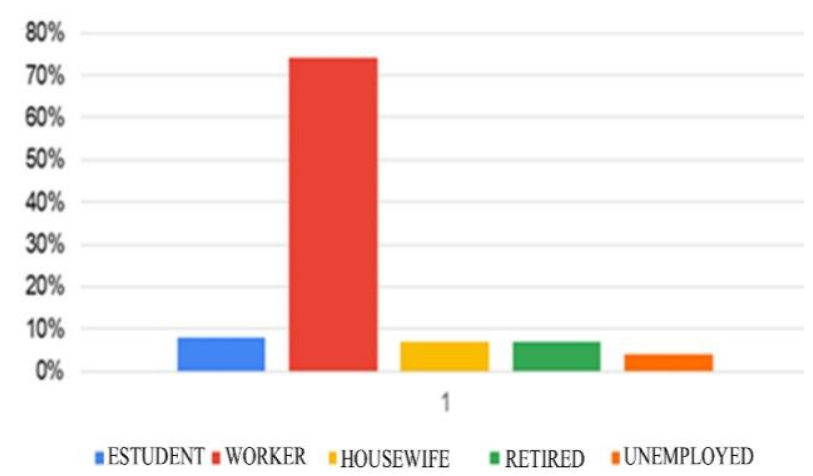

Graphic 2Occupation of the population of Santa Isabel de las Lajas, Cienfuegos; Cuba Source: Own elaboration

Although a percentage of the population is employed (working), being able to generate a regional integration strategy between the city of Cienfuegos and Santa Isabel de las Lajas that allows the establishment of alternative economic activities to those already established, will offer a work space, whether through employment or self-employment, to the unemployed population or even to those who are looking for extra income, regardless of whether they are studying, are housewives or are already retired. 
It should be pointed out that this regional and local linkage between the two cities is nothing new; there are countless examples of tourist routes, or the integration of a locality into an already established economic dynamic in the region through tourism. These are regional and/or local development strategies. "the importance of the institutionalisation of tourist routes for their development, and the situation of wine tourism routes in La Rioja, with one already created which is Rioja Alta Wine Route, but also with other opportunities that would range from a broader and more general Rioja wine route in La Rioja, to other areas such as Rioja Baja which has launched the Eastern Rioja Wine Route in 2018." (Cabello, 2019, p. 10)

\subsection{Impressions about tourism in the municipality of Santa Isabel de las Lajas, Cienfuegos, Cuba}

$94.08 \%$ of the population agrees with the implementation of tourism in the municipality and only $5.92 \%$ think the opposite, $94.58 \%$ of the population considers that tourism could be a source of employment for the local population and the other $5.42 \%$ say that it is not. $85.71 \%$ of the people say that they are willing to participate in the development of a tourism project in the municipality and only $14.29 \%$ say the opposite. With regard to the tourist resources that the inhabitants consider the municipality has, the majority believe that they are cultural $(72.90 \%)$, above all linked to the figure of Benny Moré, his artistic and cultural legacy, as well as folkloric expressions; only $14.28 \%$ believe that it has natural resources that could be used as a tourist attraction.

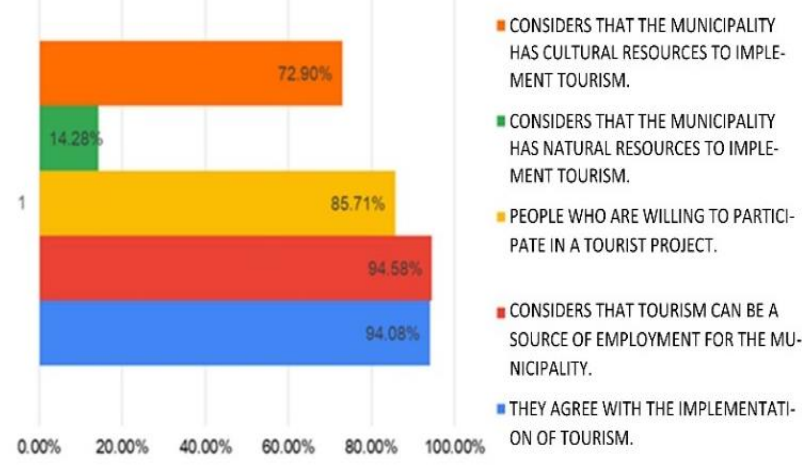

Graphic 3 Potential and perception of tourism in Santa Isabel de las Lajas, Cienfuegos; Cuba

Source: Own elaboration
In general, there is a general acceptance and openness to explore the alternative of tourist activities as a source of new opportunities for the participation of the population to attract visitors to Cienfuegos; according to the methodology proposed by Gallicchio, this is a condition of the greatest importance, together with the incorporation of the State and the Universities in this research, and there has also been an approach with the administration of the territory of Cienfuegos, who have shown interest in exploring the proposal that is being constructed and from which the writing that is now being read is presented.

In this context, the participation of the State in the present research was of the greatest relevance, since it must be remembered that the Free and Sovereign Republic of Cuba, in its productive organisation, has a model in which the State is the regent of the productive orientation and in general of the economy; thus, Enrique Gallicchio's scheme contemplates it as a fundamental axis to achieve Local Development; the union of the efforts of the State-Universities and population are present in the research.

\section{Conclusions}

Cuba's form of productive organisation means that the proposal must include the participation of the state, seeking to ensure that it is successful and that it serves as an element within the regional economy, offering new economic spaces that increase the supply of employment opportunities for obtaining a family income. From this, a public policy of promotion and integration to the tourist activity that is carried out in Cienfuegos would attract it to Santa Isabel, in the form of tourist tours, and create a regional economic circuit. "In addition to diversifying the economy of the municipality, tourism promotes the development of the production of the supply sectors of the local tourist companies" (Acerenza, 2008, p. 34).

Carrying out research using the Participatory Action Research approach is something new in the way of working on regional or local development proposals in the Republic of Cuba, since the mechanisms for achieving this, in the way of organising production, tend to be very hierarchical. 
Having an incipient approach to the Cuban state, in its state dimension, allows this research approach to approach the construction of local-regional development proposals where the proposal is built from the social base; thus having a way of proposing regional-local activities under a different methodology. This does not mean that what is currently being done is wrong, nor does it mean that the PAR approach is the most perfect; it will only be a different way of working locally and regionally, and if it is considered an acceptable alternative for the construction of proposals for economic activities, it will have been an additional contribution.

The advances made in the research allow us to observe that there are considerably acceptable conditions to continue working on the construction of the regional-local development proposal; we have the approval of a high percentage of the resident population of the object of study, the mayor's office shows interest in supporting the research, closing with the interest of the University to continue advancing in the research. This being the case, there is the participation of: State-University-population.

Finally, it is stated that as this is a study that starts from a cross-cutting sustainability logic, it has not been possible to detect, at the cut-off point for this publication, how to incorporate natural potentialities; but as they are incorporated, it is established that the carrying capacity should not be exceeded, seeking to reduce the ecological footprint at a sustainable level. On the social side, the incorporation of workshops to raise awareness among the resident population that it is not a question of disrupting the culture, but that the visitor is incorporated into the social dynamics for the time of their stay, so as not to affect the native culture, and that it is a unique experience for the visitor.

\section{References}

Alburquerque Llorens, F. (2004). Desarrollo económico local y descentralización en América Latina. Revista de la CEPAL. 82. P. 157 -171. CEPAL.
Alburquerque, F. (2004). El enfoque del desarrollo económico local. Edit. Organización Internacional del Trabajo. Argentina. Disponible en: $\quad$ https://educarse.cl/wpcontent/uploads/2017/12/EmprendimientoLocal-.pdf

Acerenza, M. (2008). Gestión Municipal del Turismo. Edit. Trillas. México.

Cabello, Sergio. (2019). El potencial del enoturismo o ruta/rutas del vino en La Rioja. En: Revista El Periplo Sustentable. Núm. 19. P. 728. UAEMex. México.

Díez Martínez, D., Martí Noguera, J. J., \& Melo Fiallos, D. F. (2016). El desarrollo regional como responsabilidad social de la universidad. Caso del ecoturismo en la provincia de Tungurahua. Revista Colombiana de Ciencias Sociales, 7(1), p. 96-113. Universidad Técnica de Ambato. Ecuador.

Gallicchio, E. (2003). El desarrollo económico local. Estrategia económica y de construcción de capital social. Revista Estudios Centroamericanos, 66. [1-27]. Uruguay.

Gallicchio, E. (2013). El desarrollo local: ¿territorializar políticas o genera políticas territoriales?. Reflexiones desde la práctica. Eutopía, Revista de Desarrollo Económico Territorial, (1), 1123. https://doi.org/10.17141/eutopia.1.2010.93 3

Gallicchio, E. \& Camejo, A. (2005). Desarrollo local y descentralización en América Latina. Nuevas alternativas de Desarrollo. DIBACLAEH. Uruguay.

Grupo Municipal para las Estrategias de Desarrollo Local MEP. (2018) Informe de las perspectivas de gobierno y otros actores institucionales. Gobierno Municipal Santa Isabel de las Lajas, Cienfuegos. Cuba.

Martín, M. E., Olite, P. R. P., \& Robaina, L. L. (2012). Centro Universitario Municipal LajasGobierno: un ejemplo de integración para la elaboración, seguimiento y monitoreo de la estrategia de desarrollo local. Desarrollo local sostenible, (14) [2]. Cuba. 
Olivé, J. M. (2002). La investigación: acción participativa, estructura y fases. Universidad Complutense de Madrid. España.

Ortiz, M. \& Borjas, B. (2008). La Investigación Acción Participativa: aporte de Fals Borda a la educación popular. Espacio Abierto, 17(4). P. 615-627. Venezuela. Recuperado de http://www.redalyc.org/articulo.oa?id=1221 7404

Troitiño, M. A., Troitiño, L. (2016). Patrimonio y turismo: reflexión teórico conceptual y una propuesta metodológica integradora aplicada al municipio de Carmona (Sevilla, España). Revista electrónica de geografía y ciencias sociales. (20). P. 1-45. Universidad de Barcelona. España. Recuperado de http://revistes.ub.edu/index.php/ScriptaNova /article/view/543/19719

Vázquez Barquero, A. (2000). Desarrollo económico local y descentralización: aproximación a un marco conceptual. CEPAL. Chile. 